IRSTI 06.51 .51

\author{
Myrzakhmetova A.M. ${ }^{1}$, Balapan A. ${ }^{2}$ \\ ${ }^{1}$ Candidate of Economic Sciences, Associate Professor, e-mail: aidam201167@gmail.com \\ ${ }^{2} 1$ course of Master's degree student, e-mail: white_jol@126.com \\ Department of International Relations and World Economy, \\ Faculty of International Relations, \\ al-Farabi Kazakh National University, Kazakhstan, Almaty
}

\title{
THE PROBLEMS AND PROSPECT \\ OF TRADE ECONOMIC COOPERATION BETWEEN CHINA AND KAZAKHSTAN
}

\begin{abstract}
China officially proposed the strategy 'one belt one road' in 2013, which aims to jointly faciliate the regional economic intergration by strengthening cooperation with neighboring countries. After the strategy 'one belt one road' had been proposed, Kazakhstan, as a necessary part of the Silk Road, and China will develop further exchange and communication in economics, politics, culture. The geographical location of China and Kazakhstan are border to each other and their resources can complement each other's needs. These conditions give important opportunity and juncture for two countries on trade cooperation and mutual investment. The aim of this article is to reveal the main problems of trade cooperation between China and Kazakhstan. This article takes the industrial cooperation between China and Kazakhstan as the research object, analyzes the current trade between China and Kazakhstan and the significance of industrial cooperation. Methodology of the article consists of mathematical analysis, scientific analysis and synthesis, statistical methods, historical method. Finally discuss the further opportunities for economic and trade cooperation between the two countries according to the current economic situation. The main conclusion of the article consists of idea that Kazakhstan and China need to deepen and expand their trade relations.
\end{abstract}

Key words: Trade cooperation, industry cooperation, one belt one road, Kazakhstan.

$$
\begin{gathered}
\text { Мырзахметова А.М. }{ }^{1} \text {, Балапан А. } \\
\text { 'экономика ғылымдарының кандидаты, доцент, e-mail: helpam201167@gmail.com } \\
21 \text { курс магистранты, е-таil: white_jol@126.com } \\
\text { халықаралық, қатынастар факультеті, халықаралық, қатынастар және } \\
\text { әлемдік экономика кафедрасы, әл-Фараби атындағы Қазақ, ұлттық университеті, } \\
\text { Қазақстан, Алматы қ. }
\end{gathered}
$$

\section{Қытай мен Қазақстан арасындағы сауда-экономикалық ынтымақтастық мәселелері мен келешегі}

Қытай 2013 жылы ресми түрде көрші елдермен ынтымақтастықты нығайту арқылы өңірлік экономикалық интеграцияны бірлесіп нығайтуға бағытталған «Бір белдеу - бір жол» атты стратегиясын ұсынды. «Бір белдеу - бір жол» стратегиясы ұсынылғаннан соң Қазақстан Жібек жолының ажырамас бөлігі ретінде Қытаймен экономика, саясат және мәдениет саласында одан әрі алмасуларды дамытады. Қытай мен Қазақстан шекаралас мемлекеттер болған соң екі мемлекет ресурстары бір-бірінің қажеттіліктерін толықтыра алады. Бұл мүмкіндіктер екі елдің сауда ынтымақтастық, пен өзара инвестициялар саласында бірігуге мүмкіндік береді. Мақаланың мақсаты - Қытай мен Қазақстан арасындағы сауда саласындағы ынтымақтастықтың негізгі мәселелерін анықтау. Мақаланың зерттеу объектісі ретінде Қытай мен Қазақстан арасындағы өнеркәсіптік ынтымақтастық қарастырылады, сонымен қатар оның маңыздылығы мен Қытай мен Қазақстан арасындағы қазіргі сауда-саттық зерттеледі. Мақаланың әдіснамасы математикалық та^даудан, ғылыми та^дау мен синтезден, статистикалық, әдістерден, тарихи әдіспен тұрады. 
Бастысы қазіргі экономикалық жағдайға сәйкес екі ел арасындағы экономикалық және саудаэкономикалық ынтымақтастықты одан әрі дамыту мүмкіндіктері талқыланады. Мақаланың басты қорытындысы - Қазақстан мен Қытайдың сауда қатынастарын тереңдету және кеңейту қажет.

Түйін сөздер: сауда ынтымақтастығы, салалық, ынтымақтастық, бір белдеу бір жол, Қазақстан.

\author{
Мырзахметова А.М. ${ }^{1}$, Балапан А. ${ }^{2}$ \\ ${ }^{1}$ кандидат экономических наук, доцент, е-mail: aidam201167@gmail.com \\ ${ }^{2}$ магистрант 1 курса, e-mail: white jol@126.com \\ кафедра международных отношений и мировой экономики, \\ факультет международных отношений, Казахский национальный университет им. аль-Фараби, \\ Казахстан, г. Алматы
}

\title{
Проблемы и перспективы торгово-экономического сотрудничества между Китаем и Казахстаном
}

\begin{abstract}
Китай официально преАложи^ стратегию «ОАин пояс - один путь» в 2013 году, целью которой является совместное укрепление региональной экономической интеграции путем укрепления сотрудничества с соседними странами. После предложения стратегии «ОАин пояс - один путь» Казахстан как неотъемлемая часть Шелкового пути и Китай будут развивать Аальнейший взаимообмен в экономике, политике и культуре. Китай и Казахстан граничат, соответсвенно, их ресурсы могут Аополнять потребности Аруг Аруга. Эти условия позволяют Авум странам объединиться в области торгового сотрудничества и взаимных инвестиций. Цель статьи - выявить основные проблемы торгового сотрудничества между Китаем и Казахстаном. В этой статье рассматривается промышленное сотрудничество между Китаем и Казахстаном как объект исследования, анализируется текущая торговля между Китаем и Казахстаном и значение промышленного сотрудничества. Методология статьи состоит из математического анализа, научного анализа и синтеза, статистических методов, исторического метода. И, наконец, обсуждаются дальнейшие возможности экономического и торгового сотрудничества межАу Авумя странами в соответствии с текущей экономической ситуацией. Основной вывод статьи состоит в том, что Казахстану и Китаю необходимо углублять и расширять свои торговые отношения.
\end{abstract}

Ключевые слова: торговое сотрудничество, отраслевое сотрудничество, ОАин пояс - один путь, Казахстан.

\section{Introduction}

The proposition of the great strategic concept of 'the Belt and Road' is not only an important strategic plan for accelerating our country's economic transition but also the comprehensive product of the current regional economic integration in full swing. When conducting economic and trade cooperation with other countries along the route, a reasonable geographical location and industrial choice are the important impetus to building 'the belt and road' initiative. The Belt and Road runs through the three continents of Europe, Asia and Africa. Central Asia is one of the key destinations for cooperation. At present, Kazakhstan is China's largest trading partner among Central Asian countries. In addition, the country has the fastest economic growth and greatest economic strength among Central Asian countries in recent years. China is Kazakhstan's second largest trading partner. China and Kazakhstan are bordering each other so their resources can complement each other's needs; such advantages give opportunities and junctures for two countries to carry out trade cooperation and mutual investment. Therefore, studying the industrial cooperation between China and Kazakhstan has great significance to the continued development of the two countries and is conducive to adjusting their foreign policies, which can broaden the areas of cooperation and achieve win-win results. The main problem set in the article is - of which grade mutual trade and economic relations are beneficial for both sides. The main hypothesis was that they are highly beneficial because of complimentary interests of countries directed to each other. Research structured that way: first of all the modern situation of trade cooperation between countries was investigated using mathematical methods and graphical analysis. Second, the grade of importance of trade relations was revealed and analyzed using historical method and scientific synthesis. Finally, ideas of both parts were generalized in conclusion. 


\section{Methodology}

In alignment with the aims of the paper, the authors apply three main methodological tools:

1) In order to show the complete picture of the trade and economic cooperation between the two countries, we analyzed many scientific publications of domestic and foreign authors, as well as state programs and agreements over the last decade on this topic.

2) To draw a figure illustrating dynamics of the trade combined degree (TCD) authors analyzed mainly the statistical sources connected with trade between China and Kazakhstan. These sources have given to the authors all necessary numerical data from 2000 to 2014 years.

3) The authors present detailed of the problems and perspectives of trade and economic relations between China and Kazakhstan.

The authors used the following research methods: from simple to complex, from the abstract to concrete, the unity of historical and logical components, methods of statistical and economic analysis, comparative analysis, methods of mathematical analysis, methods of dialectical cognition.

\section{Discussion}

Several scholars from Kazakhstan, Russia and other countries studied issues connected with trade interests of China: G.K. Zhaksygylova, E.E. Baimuhanbetova, D.Zh. Myrzahanova (Zhaksygylova. 2015: p.40), E.B. Roman'ko, A.O Musabekova (Roman'ko, 2015: p.131), N.P. Karpova (Karpova, 2015), V.V. Mozharova (Mozharova, 2011), Wang, J., Ducruet, C. (Wang, 2014: p.10), Remyga V.N. (Remyga, 2015), Kalieva A.B.(Kalieva, 2015:p. 118), Ovcharenko N., Titjuhin N. (Ovcharenko, 2016), Stepanov V. V. (Stepanov, 2012: p. 25), Sun Li (Sun Li, 2010: p.8), Hodzhaev A. (Hodzhaev, 2007: p. 38), Hafizova K.(Hafizova, 2000), Syroezhkin K.L. (Syroezhkin, 2006: p. 99). Moreover, the head of China - Xi Jingping stated the importance of developing relations between China and Kazakhstan (Xi Jingping, 2014: p. 10). Also there was a survey carried out by Asian Development Bank (Asian Development Bank, 2014). Kazakhstani scholar A. Myrzakhmetova investigated main features of Kazakhstani economy: "Kazakhstan is a developing, open, but small economy, which supplies raw materials to the world market, and this depends largely on the global market situation." (Myrzakhmetova, 2015, p. 5),
"Globalization, integration of the world economy showed strong interconnection and interdependence of the economies in the world" (Myrzakhmetova, 2016: p. 637), also Myrzakhmetova mentioned some features of transit potential of Kazakhstan (Myrzakhmetova, 2017: p.365). Chinese researcher also made their contribution. In Li Zhong-ming's work in 2014 about building 'the belt and road' initiative, with the theme of optimal allocation of intra-industry trade and production factors, he has discussed about the trade cooperation between China and other countries along the Silk Road Economic Belt (Wei Lei, 2015). Then he emphasizes that the scale and quantity of industrial cooperation should cause more attention to the rational use of factors and meanwhile increase the benefit of both parties. Li Nan had pointed out in 2015 that the economic development and the distribution of infrastructure in the countries and regions along the "Belt and Road" is not balanced, which are hard to meet the requirements of economic and trade cooperation (Cao Yuan-Zheng, 2015). However, the excessive productivity in China may just fix such problems in other countries so that the cooperation between the two sides can achieve mutual benefits and win-win results (He wei-lin).

In 2011, Zhi Zhi-Xiong and Wang Ying (Zhixiong, 2011) studied the process of industrial cooperation between China and Kazakhstan and used the indexes of trade-combined degree, rate of flow and their growth rate between Kazakhstan and other countries, reach the conclusion that China and Kazakhstan are closely related and the cooperation is stable. Jiang Li, Gao Zhi-gang (Gong Xin-shu, 2010) pointed out in 2014 that Central Asia is the key point for China's cooperation with neighboring countries, and Kazakhstan as the largest country in Central Asia, they explored the approach of cooperation in future between China and Kazakhstan through the use of game theory.

1. The Current Situation of Trade Cooperation between China and Kazakhstan

1.1 Analysis of China - Kazakhstan Trade Cooperation.

AfterChina put forward the important initiative of "the belt and road the exchange and communication of economies, politics and culture between these two countries will move towards further development. Kazakhstani scholar Tokayev analyzed the rich oil and gas resources of Kazakhstan in 2007 and China's huge demand for energy and pointed out that China and Kazakhstan have already started cooperation in the field of oil and gas development. In 2012, He Wei-lin studied the competitive advantages of 
China and Kazakhstan respectively by the basis of comparative advantage theory. Kazakhstan is rich in energy and China's domestic resources are far from meeting its own development needs. Additionally, the processing level of China's light industry is also well developed and Kazakhstan's resources are required as well.

From the perspective of bilateral trade, during the initial period of independence of Kazakhstan, the two countries mainly realized trade cooperation through simple border transportation and then gradually shifted to processing trade and leasing trade. Nowadays, bilateral trade has devloped diversely such as trade fairs, consignment trading and other forms. Industry played a decisive role in the economic development of a country. In 2012, President Nazarbayev pointed out that Kazakhstan needs to shorten the development period in order to become one of the 30 most developed countries in the world by 2050 and achieve full industrialization. Kazakhstan is rich in natural resources and has plenty of resources such as coal, oil and natural gas, which are also important for its development. The available known resources include 3 trillion cubic meters of natural gas, 4 billion tons of oil and so forth. Its national pillar industry, the mining industry, is far ahead from its total industrial output. Taking 2013 as an example, the mining industry has a total value of 72.18 billion U.S. dollars, accounting for $60.3 \%$ of the total. On the contrary, light industrial development has a weak foundation and slow development, accounting for less than $1 \%$ of the manufacturing industry and $0.34 \%$ of the total industry, mainly due to China's import and processing. At present, the deficiencies in the industrial sector in Kazakhstan are internal imbalances in the structure, lack of innovation capability, the decline in the number of small and medium-sized industrial innovative enterprises and the lack of sustainability in development. It is necessary for the government and enterprises work together to improve this situation to formulate policy proposals and rely on innovation and technology to boost the industrial standard.

According to the data of 2014 , both sides are actively engaged in trade cooperation. Among them, the first category of Kazakhstan's exports to China is mineral products, followed by base metals (products) and chemical products, accounting respectively for $64.9 \%, 19.9 \%$ and $12.2 \%$ of its total exports to China. In terms of imports, the first major category of Kazakhstan's imports from China is electromechanical products, accounting for $42.5 \%$ of its total imports from China. It is seen from the above that the trade between China and Kazakhstan has strong complementarities. Kazakhstan mainly exports the primary products such as energy and resources to China and imports mainly manufactured products.

1.2 Analysis on the Combination of trade between China and Kazakhstan.

With the deepening cooperation between China and Kazakhstan, the extent and reliance on each other's economy have increased. The trade combined degree (TCD) is usually used to measure the trade interdependency between the two countries on each other.

The calculation formula is as follows: $\mathrm{TCDij}=$ (Xij / Xi) / ( Mj / Mw)

TCDij represents the measure of the degree of combination, Xij refers to the country i's exports to country $\mathrm{j}$, Xi means the total exports of country $\mathrm{i}$, $\mathrm{Mj}$ represents the total imports of country $\mathrm{j}$, and $\mathrm{Mw}$ represents the world's total imports.

The value of trade combined degree is usually compared with 1, when TCDij is bigger than 1, the representative shows that the two countries have a high degree of combination and close trade relations. When TCDij is less than 1, the two countries have lower combination and loose trade relations.

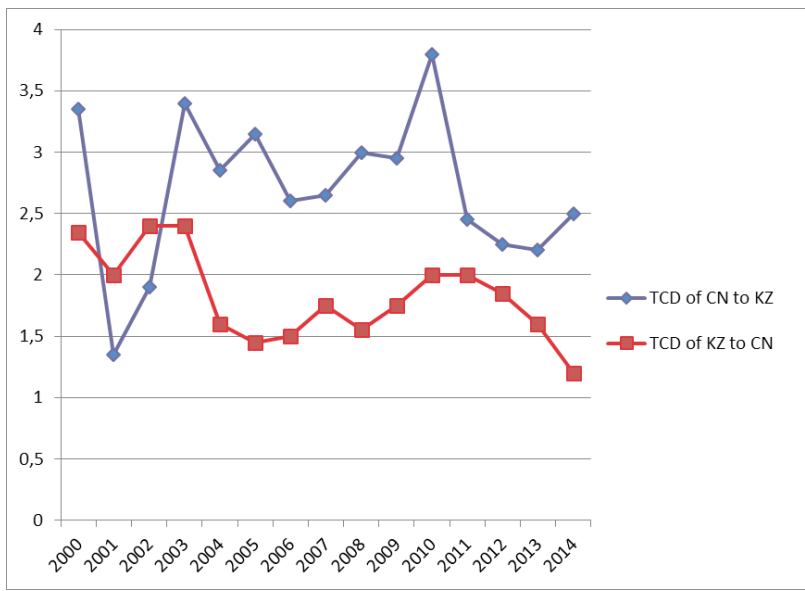

Figure 1 - The trade combined degree and the trade value between China and Kazakhstan

Source: Calculated based on the UN Comrade database (UN Comtrade data, 2016).

The trade-combined degree between China and Kazakhstan has always been greater than 1 , indicating that bilateral trade between China and $\mathrm{Ka}$ zakhstan is intimate, and the trade combined degree between Kazakhstan and China is relatively stable. However, the graph shows some divergence between 
TCD of China to Kazakhstan and TCD of Kazakhstan to China, and the first is higher than second. This means that trade interests of both countries are slightly different. In general, the trade-combined degree from China to Kazakhstan is higher than Kazakhstan to China, indicating that China is more dependent on the trade of Kazakhstan. This suggests that China is interested in exporting its goods and services to Kazakhstan, and Kazakhstan depends on imports from China.

Results 2. The Importance of Economic and Trade Cooperation between China and Kazakhstan

2.1 Promote friendly the developmental relations between the two countries.

Since China and Kazakhstan established diplomatic relations in 1991, the leaders of the two countries have visited the other country on many occasions. In 1997, China purchased 60\% stakes in Kazakhstan Aktyubinsk Oil Company and exchanged views on the implementation of the Kazakhstan-China Petroleum Cooperation Agreement. After China acceded to the World Trade Organization in 2001, China formulated and implemented the the great western development strategy, then formulated a series of preferential policies and supporting strategies in Xinjiang, which makes the trade cooperation between the two countries even closer. In 2002, China and Kazakhstan signed the treaty of good-neighborliness and friendship and cooperation. In 2003, these two countries established the strategic cooperation partnership between Kazakhstan Electricity Grid Operating Company (KEGOC) and the Chinese management company. In 2005, China and Kazakhstan established a strategic partnership, in 2006 formulated and signed the cooperation strategy for the 21st century. In 2007, they signed the cooperation framework for non-resources cooperation. In August 2014, Chinese private company Geo-Jade Petroleum Corporation acquired 95\% of shares in Maten Petroleum of Kazakhstan. At present, China and Kazakhstan keep strengthening their cooperation in various industries. For example, 28 projects connected with steel, cement and other industries have been signed. Compared with the previous years, the project has greatly improved with a total investment of more than 23 billion U.S. dollars.

2.2 Optimization of the industrial structure and promotion of sustainable economic development.

The economic trade and investment exchanges between China and Kazakhstan have had a positive impact on the development of both countries. For China, cooperation with its neighbors and emerging economies undoubtedly adds another dimension to China's diplomatic interaction. It can make full use of foreign resources to make up for lack of domestic resources, and make China's economy more efficient and improve China's international status. Internally, Kazakhstan borders with Xinjiang. China-Kazakhstan cooperation is beneficial to the implementation of the strategy for the great western development strategy, providing resources and security for the "west-east gas transmission", raising the economic development level in western regions such as Xinjiang and improving the situation of unbalanced development between eastern and western regions in China, so that the domestic environment will be more stable. For Kazakhstan, the cooperation between two countries has caused the gradual narrowing of the gap between the rich and the poor in the country, the further improvement of the people's living standards and the remarkable increase in purchasing power. Another key cooperation direction between China and Kazakhstan is the field of innovations. Only constantly upgrading economic strength and technological capabilities can achieve more efficient returns in each business area and truly enhance the strength of a country. While considering economic development opportunities and risks, the two sides should conduct comprehensive analysis of various trades and investment activities in light of the risks they would face in economic cooperation and obstacles in different fields, strengthen communication and cooperation, timely adjust and issue relevant strategy, make rational planning, sothat to minimize the investment risk.

2.3 Relieve political and economic risks.

The political risks are analyzed as follows: The systems of political management along 'the belt and road' are not the same, the religious issues are complicated, some countries are even affected by the war, and the political environment lacks stability in the long term. The development of the "one belt one road" needs plenty of capital. The credit funds of banks and financial institutions are not conform respectivly with the GDP of each country along 'one belt one road', which aggravates the impediments to the flow of state funds. The friendly cooperation between the two sides can ease the political and economic risks, which mentioned above. It will not only strengthens the mutual political trust between the two countries, but also promotes the deepening political exchanges, and maintains the peace and social stability within the two countries. China is also facing the problem of overcapacity. Actively cooperate with Kazakhstan and other countries along the line of 'one belt one road' can effectively improve the utilization of production capacity, improve the 
return on investment and make rational use of funds.

From the perspective of bilateral trade volume and growth rate, the volume of import and export trade between China and Kazakhstan generally shows an upward trend, but the situation of low level and fluctuation still appears. 1997-2004 China has been in a state of trade deficit. Except for 2001 and 2009 , the bilateral trade volume has been increasing. These phenomena shows that while bilateral trade between China and Kazakhstan develops, it is also constrained by other uncertainties. This situation improved in 2005-2009, and China started to show a surplus. From 2010 to 2013, China has been in a trade deficit with a larger increase in the value of the deficit than in the past. This long time deficit data shows that each of the two countries is dependent on each other and shows that the two countries have great opportunities for cooperation and space in the future, and then get better achievement on trade complementarity.

\section{Conclusion}

After the "one belt one road", strategy was proposed, more, more opportunities of industrial cooperation between the Kazakhstan and China have been created, and the amount of cooperation funds has been greatly increased. The following progress has been made: On December 14, 2014, Chinese Premier Li Ke-qiang paid a visit to Kazakhstan. Under the active exchanges and cooperation between two sides, Kazakhstan Prime Minister Massimov and Chinese Premier Li Ke-qiang reached a cooperation agreement worth a total of 14 billion U.S. dollars. On May 14, 2015, CGNPC and Kazakhstan National Atomic Energy Corporation signed 'the Memorandum of Understanding on Developing Clean Energy Cooperation'. At the same time, China and Kazakhstan are also expanding their cooperation in the field of infrastructure. For example, in the area of transportation and transport, Kazakhstan is located in the central Eurasian continent and is an important hub for connecting the trade dealing in neighboring regions. After the active investment of China and Kazakhstan, a number of railways and highways have now been developed and built to minimize trade obstacles.

Thus, Kazakhstan and China have great potential and all opportunities to expand and deepen mutually beneficial cooperation and collaboration in various fields: transit and transportation through Kazakhstan to Europe, trade growth, investment exchange, industrial cooperation and construction of new plants, joint ventures, cooperation in the field of education, training, consulting, etc. Such cooperation will bring more economic benefits to our countries.

\section{Литература}

1 Жаксыгылова, Г.К., Баимуханбетова, Е.Е., Мырзаханова, Д.Ж. (2015). Транспортно-логистическая система Казахстана: реалии и перспективы // Вестник КазЭУ. - №1. - 39-45.

2 Романько, Е.Б., Мусабекова, А.О. (2015). Совершенствование транспортно-логистической инфраструктуры и транзитного потенциала Казахстана // Вестник КарГУ. - № 2(78). - 129-135.

3 Карпова, Н.П., Бекетова, О.Ю., Пилипович, Е.Д. (02.06.2015). Создание мультимодальных логистических центров: перспективы развития в Центральной Азии // Научное сообщество студентов XXI столетия. Экономические науки: сб. ст. по мат. XXXIII междунар. студ. науч.-практ. конф, № 6(33). URL: https://sibac.info/studconf/econom/xxxiii/42271 (12.11.17).

4 Можарова, B.B. (2011). Транспорт в Казахстане: современная ситуация, проблемы и перспективы развития. URL: http://kisi.kz/ru/categories/books/posts/1-mozharova-v-v-transport-v-kazahstane-sovremennaya-sit (12.11.17).

5 Wang, J., Ducruet, C. (2014). Transport corridors and regional balance in China: the case of coal trade and logistics. Journal Of Transport Geography, № 40, SI, 3-16. DOI: 10.1016/j. jtrangeo.2014.08.009

6 Ремыга, В.Н. (2015). Экономический пояс Шелкового пути // Финансы: Теория и Практика. - №6 (90), URL: http:// cyberleninka.ru/article/n/ekonomicheskiy-poyas-shelkovogo-puti (12.11.2017).

7 Калиева, А.Б. (2015). Экономический пояс Великого Шелкового пути // Вестник КазНУ. - №3(71). - 117-120.

8 Овчаренко, Н., Титюхин, Н. (2016). Модель транспортно-логистической системы Казахстана. URL: https://lobanovlogist.ru/library/all_articles/55594 (12.11.17).

9 Степанов, В. В. (2012). Особенности торгово-экономического сотрудничества Китайской Народной Республики и Республики Казахстан // История и археология: материалы Междунар. науч. конф., Санкт-Петербург, Реноме, 24-26.

10 Сун Ли. (2010). Проблемы и перспективы торгово-экономического сотрудничества между Казахстаном и КНР // Вестник КазНУ. - №5. - 7-11.

11 Ходжаев, А. (2007). О центральноазиатской политике КНР (на основе китайских источников). Центральная Азия и Кавказ. - № 3. - 38 .

12 Хафизова, К. (2000). Казахско-китайская граница в прошлом и сегодня // Многомерные границы Центральной Азии. - №. 2. - М. / Под ред. М.Б. Олкотт и А. Малашенко URL: https://yvision.kz/post/284440 
13 Сыроежкин, К.Л. (2006). Проблемы современного Китая и безопасности в Центральной Азии. Алматы: Казахстанский институт стратегических исследований при Президенте Республики Казахстан, 300 с.

14 Xi Jingping, (2014). About public administration. Beijing: Publishing house liters in foreign languages.

15 Asian Development Bank. (2014). The operationalization of economic corridors in Central Asia: Study on the example of the Almaty-Bishkek Corridor. Mandaluyong, Philippines: Asian Development Bank, 65. URL: https://think-asia.org/handle/11540/2249

16 Myrzakhmetova, A.M. (2015). Kazakhstan: Devaluation. World policy journal, The Unknown, Issue 2. P. 5

17 Myrzakhmetova, A.M. (2016). The impact of international currency relations on the monetary policy of Kazakhstan. SGEM 2016 International Multidisciplinary Scientific Conference on Social Sciences and Arts, 637-643.

18 Myrzakhmetova, A.M. (2017). Central Asia as a Transcontinental Transport Bridge Based on the Transport and Logistic System of the Countries of this Region. International Journal of Economic Research, Serials Publications Pvt. Ltd. Vol. 14, №7, 365382

19 Wei Lei. (2015). 'Silk Road Fund boosts 'One belt, one road' interoperability', Jornal of Finance and Accounting for International Commerce

20 Cao Yuan-Zheng. (2015). 'PPP mode open up a new phase of 'one belt, one road' infrastructure construction', Jornal of International Project Contracting \& Labour Service

21 He Wei-lin. (2012). 'Analysis of Economic and Trade Cooperation between China and Kazakhstan', Jornal of Market Modernization

22 Cheng Xiao-li, Gong Xin-shu. (2010). 'An Empirical Analysis of the Economic Complementarity between China-Xinjiang and Kazakhstan' Jornal of Market Forum.

23 Gao Zhi-xiong, Wang Ying. (2011). 'An Empirical Analysis on the Prospects of Economic and Trade Cooperation between China and Kazakhstan - Based on the International Comparison of Trade and Investment', Jornal of International Trade.

24 Cheng Xiao-li, Gong Xin-shu. (2010). 'An Empirical Analysis of the Economic Complementarity between China-Xinjiang and Kazakhstan' Jornal of Market Forum.

25 International trade in goods and services based on UN Comrade data (2016) URL: https://comtrade.un.org/labs/dit-trade-vi $\mathrm{S} /$ ?reporter=398\&type $=$ C\&year $=2016 \&$ flow $=2(12.11 .17)$

\section{References}

1 Asian Development Bank. (2014). The operationalization of economic corridors in Central Asia: Study on the example of the Almaty-Bishkek Corridor. Mandaluyong, Philippines: Asian Development Bank, 65. URL: https://think-asia.org/handle/11540/2249

2 Cao Yuan-Zheng. (2015). 'PPP mode open up a new phase of 'one belt, one road' infrastructure construction', Jornal of International Project Contracting \& Labour Service.

3 Cheng Xiao-li, Gong Xin-shu. (2010). 'An Empirical Analysis of the Economic Complementarity between China-Xinjiang and Kazakhstan' Jornal of Market Forum.

4 Cheng Xiao-li, Gong Xin-shu. (2010). 'An Empirical Analysis of the Economic Complementarity between China-Xinjiang and Kazakhstan' Jornal of Market Forum.

5 Gao Zhi-xiong, Wang Ying. (2011). 'An Empirical Analysis on the Prospects of Economic and Trade Cooperation between China and Kazakhstan - Based on the International Comparison of Trade and Investment', Jornal of International Trade.

6 Hafizova, K. (2000). Kazahsko-kitajskaja granica v proshlom i segodnja [The Kazakh-Chinese border in the past and today]. Mnogomernye granicy Central'noj Azii, №. 2,M. Under red. M.B. Olkott i A Malashenko. URL: https://yvision.kz/post/284440

7 Hodzhaev, A. (2007). O central'no-aziatskoj politike KNR (na osnove kitajskih istochnikov). Central'naja Azija i Kavkaz [On the Central Asian policy of the PRC (based on Chinese sources)], № 3, 38.

8 He Wei-lin. (2012). 'Analysis of Economic and Trade Cooperation between China and Kazakhstan', Jornal of Market Modernization.

9 International trade in goods and services based on UN Comtrade data (2016) URL: https://comtrade.un.org/labs/dit-trade-vi $\mathrm{s} /$ ?reporter=398\&type $=$ C\&year $=2016 \&$ flow $=2(12.11 .17)$

10 Karpova, N.P., Beketova, O.Y., Pilipovich, E.D. (02.06.2015). Sozdanie mul’timodal'nyh logisticheskih centrov: perspektivy razvitija $v$ central'noj azii [Creation of multimodal logistics centers: development prospects in central asia]. Nauchnoe soobshhestvo studentov XXI stoletija. jekonomicheskie nauki: sb. st. po mat. XXXIII mezhdunar. stud. nauch.-prakt. Konf, № 6(33). URL: http://sibac.info/archive/economy/6(33).pdf (02.11.17).

11 Kalieva, A.B. (2015). Jekonomicheskij pojas Velikogo Shelkovogo puti [The economic belt of the Great Silk Road]. KazNU Bulletin, №3(71), 117-120.

12 Mozharova, V.V. (2011). Transport v Kazahstane: sovremennaja situacija, problemy i perspektivy razvitija [Transport in Kazakhstan: current situation, problems and development prospects. Almaty.]. URL: http://kisi.kz/ru/categories/books/posts/1mozharova-v-v-transport-v-kazahstane-sovremennaya-sit (12.11.2017).

13 Myrzakhmetova, A.M. (2015). Kazakhstan: Devaluation. World policy journal, The Unknown, Issue 2. P. 5.

14 Myrzakhmetova, A.M. (2016). The impact of international currency relations on the monetary policy of Kazakhstan. SGEM 2016 International Multidisciplinary Scientific Conference on Social Sciences and Arts, 637-643.

15 Myrzakhmetova, A.M. (2017). Central Asia as a Transcontinental Transport Bridge Based on the Transport and Logistic System of the Countries of this Region. International Journal of Economic Research, Serials Publications Pvt. Ltd. Vol. 14, №7, 365-382 
16 Ovcharenko, N., Titjuhin, N. (2016). Model' transportno-logisticheskoj sistemy Kazahstana. [Model of transport-logistical system of Kazakhstan]. URL: https://lobanov-logist.ru/library/all_articles/55594 (12.11.17).

17 Roman'ko, E.B., Musabekova, A.O. (2015). Sovershenstvovanie transportno-logisticheskoj infrastruktury i tranzitnogo potenciala Kazahstana [Improvement of transport and logistics infrastructure and transit potential of Kazakhstan]. Vestnik KarGU, № 2(78), 129-135.

18 Remyga, V.N. (2015). Jekonomicheskij pojas Shelkovogo puti [The economic belt of the Silk Road]. Finansy: Teorija i Praktika, №6 (90). URL: http://cyberleninka.ru/article/n/ekonomicheskiy-poyas-shelkovogo-puti (12.11.2017).

19 Stepanov, V. V. (2012). Osobennosti torgovo-jekonomicheskogo sotrudnichestva Kitajskoj Narodnoj Respubliki i Respubliki Kazahstan [Features of trade and economic cooperation of the People's Republic of China and the Republic of Kazakhstan] Istorija i arheologija: materialy Mezhdunar. nauch. konf, Saint-Petersnurg,Renome, 24-26.

20 Sun Li. (2010). Problemy i perspektivy torgovo-jekonomicheskogo sotrudnichestva mezhdu Kazahstanom i KNR [Problems and prospects of trade and economic cooperation between Kazakhstan and China]. KazNU Bulletin, №5, 7-11.

21 Syroezhkin, K.L. (2006). Problems of modern China and security in Central Asia - Almaty: Kazakhstan Institute for Strategic Studies under the President of the Republic of Kazakhstan. 300 p.

22 Xi Jingping. (2014). About public administration. Beijing: Publishing house liters in foreign languages. 2014

23 Wang, J., Ducruet, C. (2014). Transport corridors and regional balance in China: the case of coal trade and logistics. Journal Of Transport Geography, № 40, SI, 3-16. DOI: 10.1016/j. jtrangeo.2014.08.009

24 Wei Lei. (2015). 'Silk Road Fund boosts 'One belt, one road' interoperability', Jornal of Finance and Accounting for International Commerce.

25 Zhaksygylova, G.K., Baimuhanbetova, E.E.,.Myrzahanova, D.Zh, (2015). Transportno-logisticheskaja sistema Kazahstana: realii i perspektivy [The system of transport and logistics in Kazakhstan: realities and prospects]. Vestnik KazEU, №1, 39-45. 